\title{
Vacuolar processing enzyme in plant programmed cell death
}

\author{
Noriyuki Hatsugai ${ }^{1+}$, Kenji Yamada ${ }^{2+}$, Shino Goto-Yamada ${ }^{2}$ and Ikuko Hara-Nishimura ${ }^{2 *}$ \\ ${ }^{1}$ Department of Plant Biology, Microbial and Plant Genomics Institute, University of Minnesota, St. Paul, MN, USA, \\ ${ }^{2}$ Department of Botany, Graduate School of Science, Kyoto University, Kyoto, Japan
}

OPEN ACCESS

Edited by:

Patrick Gallois,

The University of Manchester, UK

Reviewed by:

lan S. Wallace

The University of Nevada, Reno, USA

Eric Beers,

Virginia Tech, USA

${ }^{*}$ Correspondence:

Ikuko Hara-Nishimura

Department of Botany, Graduate School of Science, Kyoto University,

Kita-Shirakawa, Sakyo-ku, Kyoto 606-8502, Japan

ihnishi@gr.bot.kyoto-u.ac.jp

${ }^{t}$ These authors have contributed equally to this work.

Specialty section: This article was submitted to Plant

Physiology, a section of the journal Frontiers in Plant Science

Received: 11 December 2014 Accepted: 24 March 2015 Published: 09 April 2015

Citation: Hatsugai N, Yamada K, Goto-Yamada S and Hara-Nishimura I (2015) Vacuolar processing enzyme in plant programmed cell death. Front. Plant Sci. 6:234. doi: 10.3389/fpls.2015.00234
Vacuolar processing enzyme (VPE) is a cysteine proteinase originally identified as the proteinase responsible for the maturation and activation of vacuolar proteins in plants, and it is known to be an ortholog of animal asparaginyl endopeptidase (AEPNPE/legumain). VPE has been shown to exhibit enzymatic properties similar to that of caspase 1, which is a cysteine protease that mediates the programmed cell death (PCD) pathway in animals. Although there is limited sequence identity between VPE and caspase 1, their predicted three-dimensional structures revealed that the essential amino-acid residues for these enzymes form similar pockets for the substrate peptide YVAD. In contrast to the cytosolic localization of caspases, VPE is localized in vacuoles. VPE provokes vacuolar rupture, initiating the proteolytic cascade leading to PCD in the plant immune response. It has become apparent that the VPE-dependent PCD pathway is involved not only in the immune response, but also in the responses to a variety of stress inducers and in the development of various tissues. This review summarizes the current knowledge on the contribution of VPE to plant PCD and its role in vacuole-mediated cell death, and it also compares VPE with the animal cell death executor caspase 1.

Keywords: asparaginyl endopeptidase (AEP), caspase 1, hypersensitive cell death, legumain, programmed cell death, senescence, vacuolar collapse, vacuolar processing enzyme (VPE)

\section{Introduction}

Unlike necrotic cell death, which results from accidental and physical damage, programmed cell death (PCD) is a genetically regulated physiological process of cell suicide that is integral to the development and survival of eukaryotes. In animal cells, apoptosis, the most characterized form of PCD, is executed by a family of highly conserved proteinases known as caspases (Cohen, 1997). Caspases are cysteine proteases that cleave their substrates after $\mathrm{P}_{1}$ position aspartic acid residues. The amino acids preference at the $\mathrm{P}_{2}-\mathrm{P}_{4}$ positions differs among caspase family members, including the peptide sequence of YVAD for caspase 1, DEVD for caspase 3, VEID and VKMD for caspase 6 , and IETD for caspase 8.

In 1998, a proteolytic activity toward a synthetic caspase-1 substrate (N-acetyl-YVAD-MCA) was detected in tobacco plants and the activity was required for bacterially induced PCD (del Pozo and Lam, 1998). This was the first research to suggest that the presence of a caspase-like proteinase was related to plant cell death. However, because no caspase orthologs had been identified in plant genomes, the plant proteinase catalyzing the caspase-1 substrate was unknown until the vacuolar processing enzyme (VPE) was identified as a plant proteinase with a caspase-1-like activity (Hatsugai et al., 2004). 
Homology searches have uncovered the existence of several metacaspases in plants that contain the caspase-conserved domains, and they have been proposed to play a role in plant PCD (Uren et al., 2000; Coll et al., 2011) (Table 1). However, metacaspases lack the aspartic acid specificity of caspases, and they cleave their substrates after arginine and lysine residues (Tsiatsiani et al., 2011). In the past decade, several groups have identified plant proteinases that exhibit caspase-like activities responsible for PCD (Table 1). The subtilisin-like serine proteases, saspase, and phytaspase, have caspase-6-like activities that are associated with pathogen-induced PCD in Avena sativa (Coffeen and Wolpert, 2004; Chichkova et al., 2010; Vartapetian et al., 2011). Additionally, in Arabidopsis thaliana, the $26 \mathrm{~S}$ proteasome $\beta$ subunit PBA1 catalyzes caspase- 3 substrates and mediates PCD during bacterial infection (Hatsugai et al., 2009; Hatsugai and Hara-Nishimura, 2010; Hara-Nishimura and Hatsugai, 2011) and xylem development (Han et al., 2012). Plant proteinases, as related to caspaselike activities, have been extensively reviewed (Lam and del Pozo, 2000; Woltering et al., 2002; Sanmartin et al., 2005; Bonneau et al., 2008; Woltering, 2010).

VPE was originally discovered as a cysteine proteinase responsible for the maturation of seed storage proteins in maturing pumpkin seeds, and it was named after its role in the proteolytic processing of various vacuolar proteins (Hara-Nishimura and Nishimura, 1987; Hara-Nishimura et al., 1991). The primary structure of VPE was deduced from the VPE cDNA of castor bean (Hara-Nishimura et al., 1993). The molecular characterization of the VPE of Arabidopsis showed that VPE is expressed not only in seeds but also in vegetative organs (Hara-Nishimura et al., 1998; Yamada et al., 2005): $\alpha$ VPE and $\gamma$ VPE mainly in vegetative organs (Kinoshita et al., 1995a), $\beta$ VPE in embryos (Kinoshita et al., 1995b), and $\delta$ VPE specifically and transiently in the two cell layers of the seed coat at an early stage of seed development (Nakaune et al., 2005). Genome databases showed that VPE homologs are widely distributed in land plants, from moss (Physcomitrella patens) and fern (Ceratopteris richardii) to seed plants. In this review, we focus on recent advances in the understanding of the role of VPE in plant PCD. VPE functions in various types of plant PCD are summarized in Table 2 and Figure 1.

\section{VPE has a Caspase-1-like Activity}

VPE is a vacuole-localized cysteine proteinase responsible for the maturation and activation of vacuolar proteins, which are synthesized on the endoplasmic reticulum (ER) as a proprotein precursor and are then transported to vacuoles (Hara-Nishimura and Nishimura, 1987; Hara-Nishimura et al., 1991). VPE itself is also synthesized as an inactive proprotein precursor. The proprotein precursor of VPE is self-catalytically converted into the active mature form and no other factor is necessary for activating VPE molecules (Hiraiwa et al., 1999; Kuroyanagi et al., 2002). Therefore, VPE is an initiator of the vacuolar-processing system. The pleiotropic functions of the VPE family have been reviewed extensively (Yamada et al., 2005). The self-catalytic conversion of the inactive precursor protein into functional VPE resembles the processing and activation of caspase 1 (Hiraiwa et al., 1999; Nicholson, 1999; Kuroyanagi et al., 2005).

VPEs cleave peptide bonds at the C-terminal sides of not only asparagine residues but also aspartic acids exposed on the surface of proprotein precursors to generate the respective mature proteins (Hara-Nishimura and Nishimura, 1987; Hara-Nishimura et al., 1991, 1993; Becker et al., 1995; Hara-Nishimura, 1998). VPE activity toward a synthetic VPE substrate, benzyloxycarbonylAAN-MCA, in virus-infected tobacco plants is inhibited by not only the VPE inhibitor ESEN-CHO but also caspase-1 inhibitors (Hatsugai et al., 2004). In VPE-silenced Nicotiana benthamiana plants, the reduced VPE activity parallels the reduction of caspase-1-like activity (Hatsugai et al., 2004). In addition, Arabidopsis $\gamma \mathrm{VPE}$ binds to caspase-1 inhibitors that block the selfmaturation of this enzyme and the activation of its downstream enzyme (Rojo et al., 2004). Further experiments showed that an Arabidopsis vpe-null mutant, which lacks all four VPE genes $(\alpha V P E, \beta V P E, \gamma V P E$, and $\delta V P E)$ in the genome, shows neither VPE activity nor caspase-1-like activity (Kuroyanagi et al., 2005). In addition, recombinant $\gamma \mathrm{VPE}$ recognized a VPE substrate with a $K_{\mathrm{m}}=30.3 \mu \mathrm{M}$ and a caspase- 1 substrate with a $K_{\mathrm{m}}=44.2 \mu \mathrm{M}$ but not a caspase- 3 substrate (Kuroyanagi et al., 2005). Thus, VPE recognizes aspartic acid when it is part of the YVAD sequence of a caspase-1 substrate, but does not necessarily recognize other aspartic acid residues, such as the DEVD sequence of a caspase- 3 substrate.

The similarity of the substrate specificity between VPE and caspase 1 is consistent with several structural similarities between the two enzymes, such as similar substrate pockets and similar active sites (Stennicke and Salvesen, 1998; Earnshaw et al., 1999; Hara-Nishimura et al., 2005; Hatsugai et al., 2006). Figure 2A shows essential amino acid residues forming the substrate pocket of human caspase 1 and the corresponding residues of Arabidopsis $\gamma \mathrm{VPE}$ and human AEP/VPE/legumain,

TABLE 1 | Proteinases related to PCD.

\begin{tabular}{|c|c|c|c|c|}
\hline Proteinases & Organisms & Types & $\begin{array}{l}\text { Substrate specificity } \\
\text { (residue at } P_{1} \text { position) }\end{array}$ & Cleavable caspase substrates \\
\hline VPE/AEP/legumain & Plants and animals & Cysteine proteinase & Asparagine, aspartic acid & YVAD (caspase-1 substrate) \\
\hline $26 S$ proteasome $\beta 1$ subunit & Eukaryotes & Threonine proteinase & Glutamic acid, aspartic acid & DEVD (caspase-3 substrate) \\
\hline Saspase & Plants & Serine proteinase & Aspartic acid & $\begin{array}{l}\text { VKMD (caspase-6 substrate), } \\
\text { IETD (caspase-8 substrate) }\end{array}$ \\
\hline Phytaspase & Plants & Serine proteinase & Aspartic acid & VEID (caspase-6 substrate) \\
\hline Metacaspase & Plants, Fungi, and protists & Cysteine proteinase & Arginine, lysine & \\
\hline
\end{tabular}


TABLE 2 | VPE functions in plant PCD and the related processes.

\begin{tabular}{|c|c|c|c|c|}
\hline Species & Tissues & PCD inducer & Description & References \\
\hline Nicotiana benthamiana & Leaf & Virus & $\begin{array}{l}\text { Vacuolar collapse-mediated PCD; Suppression of PCD and } \\
\text { increased viral proliferation in VPE-silenced line }\end{array}$ & Hatsugai et al., 2004, [1] \\
\hline Arabidopsis thaliana & Leaf & $\begin{array}{l}\text { Virus, bacteria, } \\
\text { fungi }\end{array}$ & $\begin{array}{l}\text { Partial PCD suppression and increased susceptibility to virus and } \\
\text { fungi in } \gamma v p e \text { mutant }\end{array}$ & Rojo et al., 2004, [2] \\
\hline Nicotiana benthamiana & Leaf & $\begin{array}{l}\text { AtCNGC11/12 } \\
\text { overexpression }\end{array}$ & $\begin{array}{l}\text { Vacuolar collapse-mediated PCD; Suppression of PCD in } \\
\text { VPE-silenced line and by caspase- } 1 \text { inhibitors }\end{array}$ & Urquhart et al., 2007, [3] \\
\hline $\begin{array}{l}\text { Malus spp. (apple } \\
\text { cultivars) }\end{array}$ & Leaf & Bacteria & Upregulation of VPE gene & lakimova et al., 2013, [4] \\
\hline Arabidopsis thaliana & Leaf & Oomycete & $\begin{array}{l}\text { Reduction of oomycete sporulation in vpe-null mutant (compatible } \\
\text { interactions presumably independent of PCD); Increase of } \gamma \mathrm{VPE} \\
\text { activity during oomycete infection }\end{array}$ & $\begin{array}{l}\text { Misas-Villamil et al., 2013, } \\
\text { [5] }\end{array}$ \\
\hline Nicotiana benthamiana & Leaf & Bacterial elicitor & $\begin{array}{l}\text { Suppressions of PCD and elicitor-induced stomatal closure in } \\
V P E \text {-silenced line }\end{array}$ & Zhang et al., 2010, [6] \\
\hline Nicotiana tabacum & $\begin{array}{l}\text { Suspension } \\
\text { cultured cell }\end{array}$ & $\begin{array}{l}\text { Oomycete } \\
\text { elicitor }\end{array}$ & $\begin{array}{l}\text { PCD suppression by caspase-1 inhibitors; Upregulation of VPE } \\
\text { genes }\end{array}$ & Gauthier et al., 2007, [7] \\
\hline Arabidopsis thaliana & Leaf & Fungal toxin & $\begin{array}{l}\text { PCD suppressions in vpe-null mutant and by inhibitors of VPE and } \\
\text { caspase-1; Inhibition of VPE activity by recombinant p35 protein }\end{array}$ & Kuroyanagi et al., 2005, [8] \\
\hline Nicotiana umbratica & Leaf & Fungal toxin & PCD suppression in VPE-silenced line & Mase et al., 2012, [9] \\
\hline Arabidopsis thaliana & Seed coat & Developmental & $\begin{array}{l}\text { PCD delay in the two cell layers of inner integument of } \delta v p e \\
\text { mutant; } \delta V P E \text {-gene upregulation and } \delta \text { VPE-protein induction }\end{array}$ & Nakaune et al., 2005, [10] \\
\hline Hordeum vulgare & Pericarp & Developmental & Upregulation of VPE gene & Radchuk et al., 2010, [11] \\
\hline Hordeum vulgare & Nucellus & Developmental & Upregulation of VPE gene with the increase of caspase-like activity & Tran et al., 2014, [12] \\
\hline Arabidopsis thaliana & $\begin{array}{l}\text { Circular-cell } \\
\text { clusters of } \\
\text { anthers }\end{array}$ & Developmental & Upregulation of $\gamma V P E$ gene & Hara-Nishimura, 2012, [13] \\
\hline $\begin{array}{l}\text { Nicotiana gossei and } \\
\text { Nicotiana tabacum F1 } \\
\text { hybrid }\end{array}$ & Seedling & $\begin{array}{l}\text { Postzygotic } \\
\text { incompatibility }\end{array}$ & $\begin{array}{l}\text { Vacuolar collapse-mediated PCD; Suppression of PCD by } \\
\text { caspase- } 1 \text { inhibitor; Increase of VPE activity }\end{array}$ & Mino et al., 2007, [14] \\
\hline Solanum tuberosum & $\begin{array}{l}\text { Tuber apical } \\
\text { bud meristem }\end{array}$ & Developmental & PCD suppression by caspase-1 inhibitor; Increase of VPE activity & $\begin{array}{l}\text { Teper-Bamnolker et al., } \\
\text { 2012, [15] }\end{array}$ \\
\hline Arabidopsis thaliana & Leaf, lateral root & $\begin{array}{l}\text { Senescence, } \\
\text { developmental }\end{array}$ & Upregulation of $\alpha V P E$ and $\gamma V P E$ genes & Kinoshita et al., 1999, [16] \\
\hline Nicotiana tabacum & Petal & Senescence & Upregulation of VPE genes & Muller et al., 2010, [17] \\
\hline Nicotiana tabacum & $\begin{array}{l}\text { Suspension } \\
\text { cultured cell }\end{array}$ & Heat stress & $\begin{array}{l}\text { Vacuolar collapse-mediated PCD; Suppression of PCD in vpe-null } \\
\text { mutant; } \gamma \text { VPE-gene upregulation and increase of VPE activity }\end{array}$ & Li et al., 2012, [18] \\
\hline Oryza sativa & Leaf & $\begin{array}{l}\text { Hydrogen } \\
\text { peroxide stress }\end{array}$ & $\begin{array}{l}\text { Vacuolar collapse-mediated PCD; PCD suppression by reduction } \\
\text { of VPE gene expression in } \mathrm{Bcl}-2 \text { overexpressor }\end{array}$ & Deng et al., 2011, [19] \\
\hline Oryza sativa & Leaf & salt stress & $\begin{array}{l}\text { PCD suppression by reduction of VPE gene expression in Bcl-2 } \\
\text { overexpressor }\end{array}$ & $\begin{array}{l}\text { Deng et al., 2011; Kim } \\
\text { et al., 2014, [20] }\end{array}$ \\
\hline Arabidopsis thaliana & $\begin{array}{l}\text { Suspension } \\
\text { cultured cell }\end{array}$ & $\begin{array}{l}\text { Ozone } \\
\text { exposure }\end{array}$ & Upregulation of $\gamma V P E$ genes & Kadono et al., 2010, [21] \\
\hline Arabidopsis thaliana & Leaf protoplast & $\begin{array}{l}\text { Ultraviolet } \\
\text { radiation }\end{array}$ & PCD suppression by caspase- 1 inhibitor and in p35 overexpressor & Danon et al., 2004, [22] \\
\hline Lycopersicon esculentum & $\begin{array}{l}\text { Suspension } \\
\text { cultured cell }\end{array}$ & Aluminum & PCD suppression by caspase- 1 inhibitor & Yakimova et al., 2007, [23] \\
\hline Nicotiana tabacum & $\begin{array}{l}\text { Suspension } \\
\text { cultured cell }\end{array}$ & Aluminum & $\begin{array}{l}\text { Vacuolar collapse-mediated PCD; Suppression of PCD by } \\
\text { caspase-1 inhibitor; VPE-gene upregulation and increase of VPE } \\
\text { activity }\end{array}$ & Kariya et al., 2013, [24] \\
\hline Nicotiana tabacum & Root & Aluminum & $\begin{array}{l}\text { PCD suppression by reduction of VPE gene expression in Ced-9 } \\
\text { overexpressor }\end{array}$ & Wang et al., 2009, [25] \\
\hline Lycopersicon esculentum & $\begin{array}{l}\text { Suspension } \\
\text { cultured cell }\end{array}$ & Cadmium & PCD suppression by caspase-1 inhibitor & Yakimova et al., 2006, [26] \\
\hline Arabidopsis thaliana & Leaf & ER stress & $\begin{array}{l}\text { Vacuolar collapse-mediated PCD; Suppression of PCD in vpe-null } \\
\text { mutant; Increase of VPE activity and caspase-1-like activity }\end{array}$ & Qiang et al., 2012, [27] \\
\hline Glycine max & Leaf protoplast & ER stress & $\begin{array}{l}\text { Upregulation of VPE gene; Identification of two transcription } \\
\text { factors for VPE gene expression }\end{array}$ & Mendes et al., 2013, [28] \\
\hline
\end{tabular}




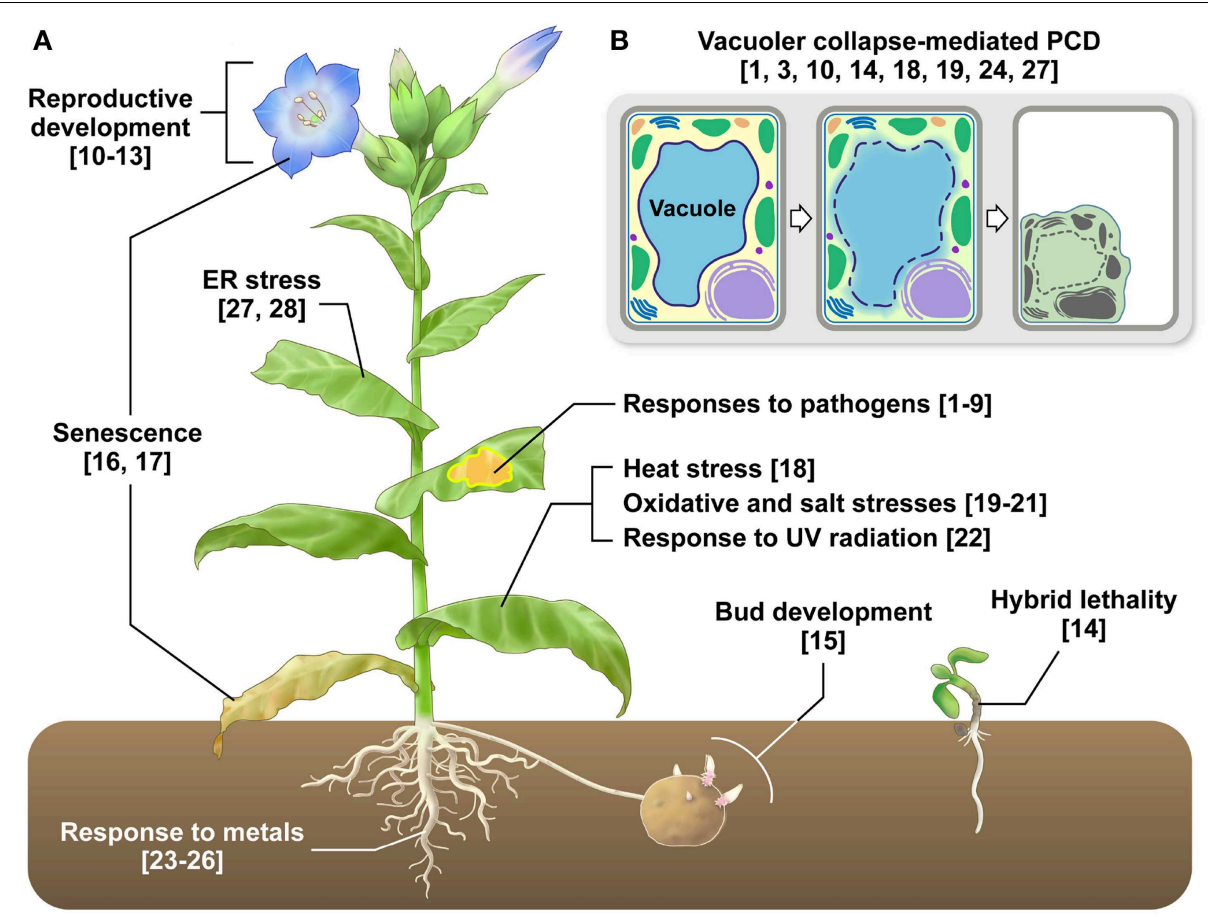

FIGURE 1 | VPE functions in various types of plant PCD. (A) VPE-mediated PCD occurs in almost all plant cells and tissues and is involved in developmental processes and responses to biotic and abiotic stresses. Refer to Table $\mathbf{1}$ for further information. The numbers are reference numbers in Table 1. (B) VPE-mediated PCD involves the collapse of vacuolar membranes, which allows vacuolar hydrolytic enzymes to be discharged into the cytosol, resulting in cell death. The numbers are reference numbers in Table $\mathbf{1 .}$ which are conserved in Opisthokonta. Our predictions of threedimensional (3D) structures reveal an interesting feature of the enzymes (Figure 2B). Surprisingly, $\gamma$ VPE Arg74, which has been thought to correspond to caspase-1 Arg179, accurately overlaps with caspase-1 Arg341. Two guanido groups of Arg341 and Arg179 of caspase 1 make strong affinity with the carboxylate group of the Asp residue in the substrate peptide YVAD (Nicholson, 1999). On the other hand, $\gamma \mathrm{VPE}$ has only one guanido group of Arg74, which makes the substrate pocket of $\gamma \mathrm{VPE}$ less positively charged than that of caspase 1 . This is consistent with the fact that $\gamma \mathrm{VPE}$ has broader substrate specificity toward Asp and Asn, while caspase 1 has narrow substrate specificity toward Asp.

\section{VPE Roles in Developmental PCD}

\section{Reproductive Development}

In angiosperm seeds, the embryo and endosperm are surrounded by the seed coat. The Arabidopsis seed coat consists of two integuments, the outer and inner, of maternal tissues, and multiple cell layers of these integuments develop after fertilization, resulting in the specialized structures of the seed coat. During the early stage of seed development, $\delta \mathrm{VPE}$ has caspase-1-like activity and is specifically expressed in two cell layers of the inner integuments of the Arabidopsis seed coat (Nakaune et al., 2005). This tissue undergoes PCD in its early stages, thereby reducing its thickness. In a $\delta V P E$-deficient mutant, however, PCD is delayed and the inner integuments remain thick throughout embryogenesis
(Nakaune et al., 2005). This indicates that $\delta \mathrm{VPE}$ is responsible for the PCD of limited cell layers during the formation of the seed coat.

In barley (Hordeum vulgare), seven VPE homologs (HvVPEs) have been identified and some may be involved in PCD during the development of maternal seed tissues, including the nucellus and pericarp (Linnestad et al., 1998; Radchuk et al., 2010; Julian et al., 2013). HvVPE4, which is weakly similar to Arabidopsis $\delta \mathrm{VPE}$, is exclusively expressed in the deteriorating pericarp associated with apoptotic DNA degradation. This correlative evidence suggested that HvVPE4 is involved in the PCD of the pericarp (Radchuk et al., 2010). HvVPE2a, known as nucellain, is reported to be localized in nucellar cell walls that degenerate in developing cereal grains (Linnestad et al., 1998; Dominguez et al., 2001). HvVPE2a may play a role in the processing and/or turnover of cell wall proteins. Further evidence supporting the involvement of HvVPE2a in nucellar PCD was provided by reports of an increased caspase-1-like activity in the nucellus and nucellar projection during the development of maternal seed tissues in barley (Tran et al., 2014). Additional genetic and biochemical investigations are required to validate the contribution of HvVPE to PCD.

\section{Hybrid Lethality}

Hybrid lethality is a common post-zygotic incompatibility and is associated with PCD (Bomblies and Weigel, 2007). The interspecific F1 hybrid of Nicotiana gossei and Nicotiana tabacum exhibits 
A

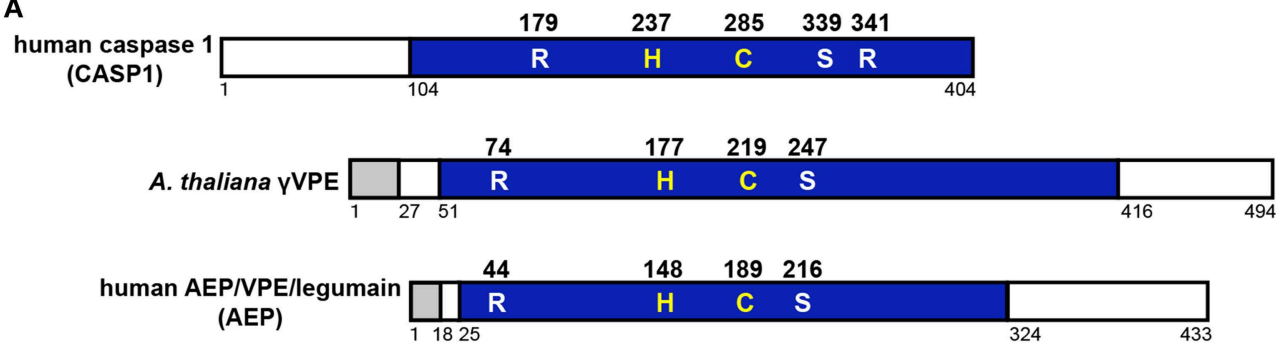

B

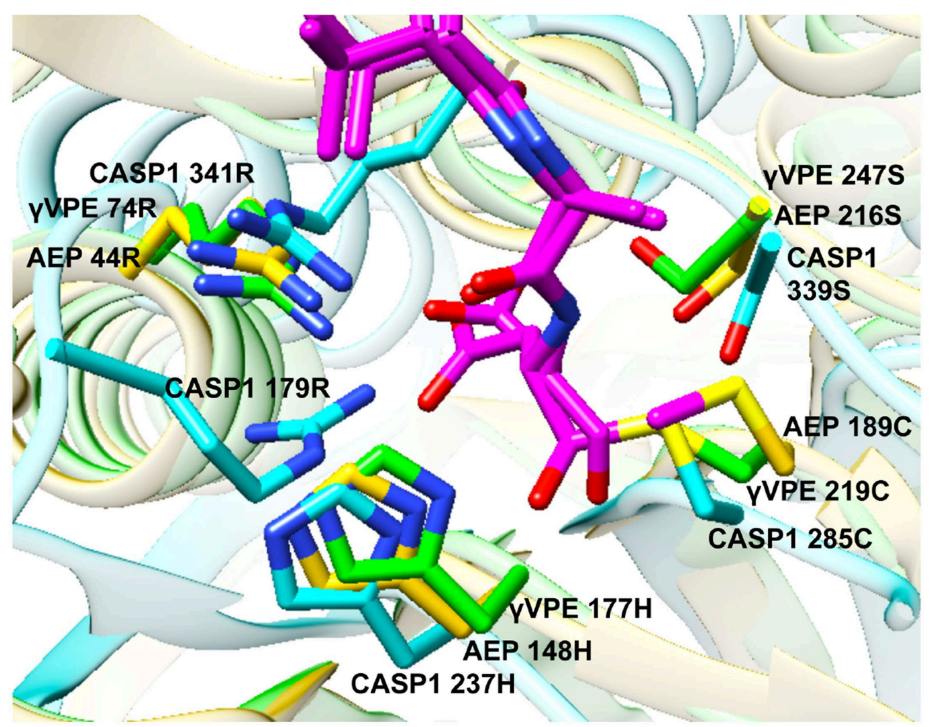

FIGURE 2 | Comparison of VPE with caspase 1. (A) Primary structural organizations of the precursor proteins of human caspase 1 (CASP1), Arabidopsis $\gamma \mathrm{VPE}$, and human AEP/NPE/legumain (AEP). The $\gamma \mathrm{VPE}$ and AEP precursors have a signal peptide (gray boxes) at the $\mathrm{N}$-termini. The proprotein precursors of $\gamma \mathrm{VPE}, \mathrm{AEP}$, and CASP1 have cleavable propeptide (open boxes). After the removal of the propeptides, proprotein precursors are converted into the respective mature enzymes (blue boxes). Shown are five essential amino acid residues forming the substrate pocket of CASP1 and their corresponding residues of $\gamma \mathrm{VPE}$ and AEP, which are members of the VPE family. His237 and Cys285 form the catalytic dyad of CASP1, whereas His177 and Cys219 form the catalytic dyad of $\gamma$ VPE. Three essential amino acids (Arg179, Ser339, and Arg341) form the substrate-binding pocket of CASP1. (B) Predicted 3D structures of the substrate pockets of CASP1, $\gamma \mathrm{VPE}$, and AEP together with the substrate peptide YVAD (magenta) using the program Phyre2 (http://www.sbg.bio.ic.ac.uk/phyre2/). Note that Arg74, His177, Cys219, and Ser247 of $\gamma$ VPE correspond to Arg341, His237, Cys285, and Ser339 of CASP1, respectively. The backbone amino acids of CASP1, $\gamma \mathrm{VPE}$, and AEP are shown in light blue, green, and orange, respectively. Oxygen, red; nitrogen, blue; sulfur, yellow. hybrid lethality at the seedling stage. The cell death in the hybrid seedling is proceeded by vacuolar collapse (Mino et al., 2007). The vacuolar collapse and cell death were suppressed by the inhibition of VPE activity, and there was a correlation between VPE activity and the breakdown of the vacuolar membrane. These results suggest that this protease is involved in the cell death underlying hybrid lethality.

\section{Bud Development and Senescence}

Furthermore, in the developmental program, VPE is associated with PCD in tuber apical bud meristems and the release of apical dominance in potato tubers (Teper-Bamnolker et al., 2012). VPE may also be related to petal and leaf senescence (Kinoshita et al., 1999; van Doorn and Woltering, 2008; Muller et al., 2010). Promoter-GUS analyses showed the up-regulation of $\alpha V P E$ and $\gamma V P E$ in dying cortex cells located next to the emerging lateral root (Kinoshita et al., 1999) and in dying circular-cell clusters of anthers during the later stage of pollen development (HaraNishimura, 2012), respectively.

\section{VPE Roles in Biotic Stimuli-Induced PCD}

\section{Responses to Pathogens}

Plants are continuously challenged by a wide variety of pathogens, such as viruses, bacteria, fungi, and oomycetes. In most cases, however, the spread of disease is limited by plant immune responses, including the hypersensitive response (HR), which is characterized by a rapid and localized PCD known as hypersensitive cell death (Greenberg, 1997). The HR is controlled by multiple signal transduction pathways that are initiated upon the recognition of a pathogen avirulence (Avr) factor by a plant resistance (R) gene product (Dangl and Jones, 2001; Jones and 
Dangl, 2006). Caspase peptide inhibitors suppress the HR in response to infection with an avirulent Pseudomonas syringae pv phaseolicola strain (del Pozo and Lam, 1998). In addition, caspase-like activity was detected in tobacco plants in response to tobacco mosaic virus (TMV) (del Pozo and Lam, 1998). This work was the first report of the involvement of caspase-like activity in plant PCD.

Studies using a virus-induced gene silencing strategy provided evidence that VPE is a proteinase exhibiting caspase-1-like activity and that, by controlling vacuolar rupture in N. benthamiana, it was essential for TMV-induced hypersensitive cell death (Hatsugai et al., 2004). The vacuolar collapse has been proposed to be the crucial event in plant cell death (Jones, 2001). An ultrastructural analysis and a viability assay showed that TMV-induced cell death was preceded by the disintegration of vacuolar membranes and that membrane disintegration continued, resulting in complete vacuolar collapse (Hatsugai et al., 2004). In contrast, $V P E$-silenced plants did not undergo vacuolar membrane disintegration or cell death (Hatsugai et al., 2004). These silenced plants also failed to show any PCD hallmarks, such as DNA fragmentation, when challenged with TMV. This observation suggests that VPE functions as a key molecule in PCD triggered by vacuolar collapse. Although the VPE deficiency does not interfere with the induction of defense genes, virus proliferation is markedly increased in the plants. These observations support the idea that PCD during the HR is critical for the removal of biotrophic pathogens, whose growth depends on the living host tissues (Greenberg and Yao, 2004).

The chimeric Arabidopsis cyclic nucleotide-gated ion channels, AtCNGC11 and AtCNGC12, act as positive regulators of $R$ gene-mediated resistance responses (Yoshioka et al., 2006; Moeder et al., 2011). AtCNGC11/12 can induce hypersensitive cell death when transiently expressed in N. benthamiana (Urquhart et al., 2007). A microscopic analysis of dying cells revealed that the cell death exhibits morphological and biochemical features of PCD, and involves vacuolar membrane rupture and vacuole collapse (Urquhart et al., 2007). Interestingly, in $V P E$-silenced plants, the development of cell death induced by AtCNGC11/12 was much slower and weaker compared with in control plants (Urquhart et al., 2007). These results indicated the involvement of VPE in AtCNGC11/12-induced cell death.

Recently, it was suggested that VPE is related to the HR induced by Erwinia amylovora in apple leaves (Iakimova et al., 2013). In addition, a role for VPE during compatible interactions between Arabidopsis and the obligate biotrophic oomycete pathogen Hyaloperonospora arabidopsidis has been demonstrated, but is presumably independent of PCD (Misas-Villamil et al., 2013). Using an activity-based probe for Arabidopsis VPE, the $\gamma \mathrm{VPE}$ activity was shown to increase during an $H$. arabidopsidis infection. Interestingly, the Arabidopsis vpe-null mutant decreased $H$. arabidopsidis sporulation, indicating that VPEs are beneficial for $H$. arabidopsidis pathogenicity. This suggested that, as an obligate biotrophic pathogen, $H$. arabidopsidis takes advantage of the increased VPE activity in the host cells. The enhanced resistance is only partial in the $\gamma v p e$ single mutant, suggesting that other VPEs also contribute to $H$. arabidopsidis sporulation.
Three elicitors, harpin, Nep1, and boehmerin, which are produced by bacteria, fungi and oomycete, respectively, induce hypersensitive cell death in N. benthamiana (Wei et al., 1992; Wang et al., 2003; Gijzen and Nurnberger, 2006). A study examined whether VPE contributed to elicitor-induced cell death (Zhang et al., 2010). After infiltration with each of the three elicitors, only harpin-induced cell death was compromised in NbVPE1a- and NbVPE1a/1b-silenced plants, suggesting that NbVPE1 a contributes to harpin-induced cell death (Zhang et al., 2010). However, hypersensitive cell death was not impaired in the gene-silenced plants in response to Nep1 and boehmerin. This was consistent with the hypersensitive cell death triggered by Nep1 in Phytophthora sojae not requiring caspase-like activity (Qutob et al., 2006). These results suggest that the molecular mechanism for hypersensitive cell death triggered by harpin differs from that triggered by Nep1 or boehmerin. Additionally, VPE may be associated with the hypersensitive cell death triggered by the oomycete elicitor, cryptogein (Gauthier et al., 2007).

Some necrotrophic pathogens secrete mycotoxins to kill host cells and promote their own growth in susceptible host plants (Walton, 1996; Markham and Hille, 2001). A fungal pathogen, Fusarium moniliforme, produces fumonisin B1 (FB1) and causes disease symptoms in maize. FB1 inhibits ceramide synthase, which is responsible for sphingolipid biosynthesis (Wang et al., 1991), resulting in PCD in Arabidopsis plants. Kuroyanagi et al. (2005) showed that FB1-induced cell death was accompanied by the disintegration of vacuolar membranes and DNA fragmentation, followed by lesion formation (Kuroyanagi et al., 2005). The features of FB1-induced cell death were completely abolished by the caspase- 1 inhibitor and in the Arabidopsis quadruple vpe-null mutant (Kuroyanagi et al., 2005). The $\gamma$ VPE expression was also increased after Botrytis cinerea, a necrotrophic fungi infection (Rojo et al., 2004).

Additionally, the $\gamma v p e$ single mutant more severely suppressed lesion formation than the other single mutants ( $\alpha v p e$, $\beta v p e$, and $\delta v p e$ ), although the suppression was not as strong as it was in the $v p e$-null mutant plants. The other VPEs possibly compensate for the lack of $\gamma \mathrm{VPE}$ in $\gamma \nu$ pe leaves. $\gamma \mathrm{VPE}$ is the most essential of the four VPE homologs for FB1-induced cell death in Arabidopsis leaves. The compensation among VPEs is not unique to PCD. It is also found in seed storage protein processing, where $\alpha \mathrm{VPE}$ and $\gamma \mathrm{VPE}$ compensate for the lack of $\beta \mathrm{VPE}$ in the $\beta v p e$ mutant (Shimada et al., 2003).

The AAL-toxin produced by the fungus Alternaria alternata $\mathrm{f}$. sp. lycopersici is a chemical congener of FB1 (Nelson et al., 1993) and causes disease symptoms in susceptible tomatoes (Wang et al., 1996) and some Nicotiana species lacking the Alternaria stem canker gene 1 (Brandwagt et al., 2000). AAL-toxin-induced cell death was suppressed in tomato by overexpressing the antiapoptotic baculovirus p35 (Lincoln et al., 2002), which is a caspase inhibitor. The recombinant p35 inhibited VPE activity in vitro (Kuroyanagi et al., 2005), suggesting that AAL-toxininduced cell death is mediated by VPE. In fact, the cell death induced by the AAL-toxin was compromised in VPE-silenced Nicotiana umbratica plants (Mase et al., 2012). Additionally, the pathogenicity of A. alternata f. sp. lycopersici was abolished in 
VPE-silenced N. umbratica plants (Mase et al., 2012). These results suggested that VPE is involved in fungal toxin-induced cell death in plants.

\section{ER Stress}

The ER is an organelle in which secretory and membrane proteins are correctly folded and assembled by chaperones. When these processes do not function properly, unfolded or misfolded proteins accumulate inside the ER, causing ER stress. Such ER stress triggers the unfolded protein response (UPR), which adjusts the protein-folding capacity to the needs of the cell, to avoid cell damage. However, prolonged ER stress eventually overwhelms the cellular protective mechanisms and ultimately results in PCD. In animals, ER stress-induced PCD involves the activation of caspase (Rasheva and Domingos, 2009). In plants, there have been several reports implicating caspase-like activities in ER stress-induced PCD (Cai et al., 2014).

Qiang et al. (2012) showed, using a cytological analysis of mutualistic interactions between Arabidopsis and Piriformospora indica, that caspase-1 and VPE activities regulated ER stressinduced PCD. The mutualistic fungi $P$. indica disturbs the UPR, which eventually leads to the death of root cells. An ultrastructural analysis showed that $P$. indica colonization was associated with ER swelling, which was followed by tonoplast rupture. In a vpe-null mutant, the tonoplast rupture was not detected and PCD was compromised, although ER swelling occurred. These results indicated that ER stress-induced vacuole-mediated cell death is dependent on VPE. VPE might additionally function downstream of UPR in the ER stress-induced PCD process. A recent report supported this hypothesis. Two NAC transcription factors, GmNAC30 and GmNAC81, that induce PCD downstream of osmotic and ER stresses, are able to interact with each other in a synergistic manner to directly activate VPE gene expression (Mendes et al., 2013).

\section{VPE Roles in Abiotic Stress-Induced PCD}

\section{Heat Stress}

Heat shock triggers PCD, with apoptotic features including cell shrinkage, chromatin condensation, and DNA fragmentation (Tian et al., 2000; Vacca et al., 2006). In heat-treated tobacco BY-2 cells, cell death has been reported to be prevented by both caspase- 1 and caspase- 3 inhibitors (Vacca et al., 2006), but the link between caspase-1-like and caspase-3-like activities and the signaling pathway leading to PCD remains to be investigated. Recent work using the Arabidopsis vpe-null mutant showed that VPE exhibited caspase-1-like activity in heat-treated leaves and promoted both vacuolar disruption and activation of caspase-3like activity (Li et al., 2012). This may provide the first evidence for the participation of VPE in the activation of a downstream caspase-3-like activity. In further studies, MAP kinase 6 (MPK6) activity was increased after heat shock treatment, and experiments with inhibitors and mutants suggested that MPK6 was responsible for the $\gamma \mathrm{VPE}$ activation and the subsequent execution of PCD. These results suggest that the activation of $\gamma \mathrm{VPE}$ was mediated by MPK6 and played an important role in heat shock-induced PCD in Arabidopsis (Li et al., 2012).

\section{Oxidative and Salt Stresses}

$\mathrm{H}_{2} \mathrm{O}_{2}$ is an important signaling molecule that regulates stressinduced plant PCD (Gechev and Hille, 2005). In rice, five VPE (OsVPE) genes were found in the genome (Christoff et al., 2014), and OsVPE2 and OsVPE3 may be involved in the $\mathrm{H}_{2} \mathrm{O}_{2}$-induced PCD. The expression levels of OsVPE2 and OsVPE3 were upregulated during $\mathrm{H}_{2} \mathrm{O}_{2}$ stress. Furthermore, the $\mathrm{H}_{2} \mathrm{O}_{2}$-induced enhancement of OsVPE2 and OsVPE3 expression levels were significantly suppressed, as was the cell death associated with vacuolar rupture in rice transgenic lines overexpressing $\mathrm{Bcl}-2$, which is a potent inhibitor of human apoptosis (Deng et al., 2011). In addition, the PCD caused by high salt stress was also effectively suppressed by Bcl-2, and the salt-induced expression levels of OsVPE2 and OsVPE3 were markedly inhibited in Bcl2-overexpressing rice lines (Deng et al., 2011; Kim et al., 2014). These results suggested that OsVPE2 and OsVPE3 are involved in $\mathrm{H}_{2} \mathrm{O}_{2}$ - and salt stress-induced PCD, and also that Bcl-2 inhibits the induced PCD by suppressing the transcriptional activation of OsVPEs in rice. $\mathrm{H}_{2} \mathrm{O}_{2}$ - and salt stress-induced PCD may share a common pathway that is suppressed by Bcl-2, thereby inhibiting the transcriptional activation of OsVPE in rice. Additional experiments, including the study of the effect of $\mathrm{H}_{2} \mathrm{O}_{2}$ andsalt stress on VPE-deficient lines, will be necessary to test this hypothesis.

The air pollutant ozone $\left(\mathrm{O}_{3}\right)$ triggers $\mathrm{H}_{2} \mathrm{O}_{2}$ production and subsequently causes visible lesion formations on leaves, which is similar to the pathogen-induced $\mathrm{HR}$. The $\mathrm{O}_{3}$-induced cell death requires caspase-like activities (Pasqualini et al., 2003; Kangasjärvi et al., 2005; Overmyer et al., 2005). The $\gamma$ VPE expression level was increased early after $\mathrm{O}_{3}$ exposure to Arabidopsis suspension cells (Kadono et al., 2010). The $\mathrm{O}_{3}$-induced up-regulation of $\gamma V P E$ was suppressed efficiently by an NADPH oxidase inhibitor (diphenyleneiodonium) and anion channel blockers (9-anthracen carboxylic acid and glibenclamide), suggesting that anion channel activation and $\mathrm{H}_{2} \mathrm{O}_{2}$ production are involved in the signaling pathway leading to a transcriptional regulation of $\gamma V P E$ for the $\mathrm{O}_{3}$-induced cell death.

\section{Response to Ultraviolet (UV) Radiation}

VPE has been implicated in the PCD induced by UV radiation (Danon et al., 2004). UV-induced DNA fragmentation and cell death were suppressed by caspase- 1 and caspase- 3 inhibitors. Furthermore, the UV-induced cell death associated with DNA fragmentation was prevented in Arabidopsis protoplasts overexpressing anti-apoptotic baculovirus p35. Because the recombinant p35 inhibited VPE activity in vitro (Kuroyanagi et al., 2005), UV-induced cell death might be mediated by VPE, as is the case with toxin-induced cell death (Lincoln et al., 2002).

\section{Response to Metals}

Aluminum is known to be toxic to plants as well as humans, and it inhibits cell division and root elongation, eventually resulting in cell death (Kochian, 1995). Aluminum-induced cell death is accompanied by typical apoptotic features, such as nuclear and DNA fragmentation and cytoplasmic condensation. 
In tomato suspension-cultured cells, cell death was abolished by a broad-range of caspase inhibitors (Yakimova et al., 2007). This was the first evidence showing the involvement of a proteinase possessing caspase-like activity in aluminuminduced PCD.

A recent study reported that a caspase-1 inhibitor, Ac-YVAD$\mathrm{CHO}$, prevented the loss of plasma membrane integrity caused by exposure to aluminum in tobacco suspension-cultured BY-2 cells (Kariya et al., 2013). Time-course experiments indicated that the VPE activity increased after the aluminum treatment, which might cause a loss of plasma membrane integrity. In addition, fluorescence microscopic observations of a transgenic cell line expressing a tonoplast-localized GFP-AtVam3p demonstrated that vacuolar rupture occurred prior to cell death in aluminumtreated cells. These results suggested that VPE-mediated vacuolar collapse was a key factor leading to aluminum-induced PCD in plants. However, how aluminum triggers an increase in VPE activity remains to be elucidated.

Additionally, a previous study revealed that the apoptotic suppressor, Ced-9, effectively inhibited aluminum-induced PCD and promoted aluminum tolerance in plants, possibly by inhibiting aluminum-induced VPE activity (Wang et al., 2009). It is likely that conserved negative regulators of PCD are involved in the integrated regulation of aluminum-induced PCD by an unidentified mechanism (Wang et al., 2009).

The caspase-1-like and VPE activities may also be associated with the PCD induced by cadmium, which is a widespread heavy metal pollutant (di Toppi and Gabbrielli, 1999). In tomato suspension-cultured cells, cadmium induced cell death within $24 \mathrm{~h}$ in a concentration-dependent manner. The cadmiuminduced cell death was almost completely abolished by the caspase-1 inhibitor Ac-YVAD-CMK and the broad-range caspase inhibitor Z-Asp- $\mathrm{CH}_{2}$-DCB. The cell death kinetics and morphological features were comparable to the effects of aluminum (Yakimova et al., 2006). These results suggest that cadmiuminduced cell death may also proceed through a VPE-mediated vacuolar system.

\section{VPE-Dependent Activation of Defense Proteins}

VPE post-translationally processes precursor proteins to produce various functional proteins in vacuoles. VPE cleaves the multiple Asn-Gln bonds of the single precursor protein PV100 to produce different functional proteins, including a proteinase inhibitor, cytotoxic peptides and a storage protein, in pumpkin seeds (Yamada et al., 1999). Interestingly, VPE catalyzes not only the peptide-bond-cleavage reaction but also the peptideligation or transpeptidation reaction. The latter reaction generates a backbone-cyclized protein, cyclotide kalata B1, from a precursor protein in sunflower seeds (Saska et al., 2007). Kalata B1 functions in defense against insect pests by inhibiting their growth (Jennings et al., 2001). Thus, VPE produces defense proteins from the inactive precursors that have cleavable Asn residues. The defense proteins also include a proteinase inhibitor of tomato leaves (Graham et al., 1985), a proteinase inhibitor of tobacco stigmas (Atkinson et al., 1993), and a basic chitinase of tobacco leaves (Sticher et al., 1993). Hence, VPE plays a key role in generating active defense proteins against pathogens.

\section{Animal AEP/VPE/Legumain}

VPE family members are widely distributed in plants and animals. Mammalian VPE homologs are also referred as to asparaginyl endopeptidase (AEP/VPE/legumain), because of the substrate specificity toward asparaginyl bonds (Chen et al., 1997). The crystal structure of human AEP was recently reported to show the asparagine-specific endopeptidase activity (Dall and Brandstetter, 2013) (Figure 2B). A study using AEP-null mice showed that AEP is required for the maturation of lysosomal proteinases (cathepsins $\mathrm{B}, \mathrm{L}$, and $\mathrm{H}$ ) and that AEP has a critical role in the degradation of cellular materials in the endosomes/lysosomes of kidney cells (Shirahama-Noda et al., 2003). The AEP-null mice also provided evidence that AEP is involved in neuronal cell death, whereby AEP appears to degrade a DNase inhibitor (SET), which is a caspase substrate, and trigger DNA damage in the brain (Liu et al., 2008). Based on these observations, a similar VPE/AEP-dependent PCD mechanism appears to function in plants and animals; processing the vacuole/lysosome degradation enzymes and then collapsing membranes to leak degradation enzymes into the cytosol during PCD.

\section{Concluding Remarks}

VPE is a plant counterpart of caspase 1 and is involved in the execution of a variety of plant PCDs. However, the subcellular localization of these enzymes is different: caspase 1 is a cytosolic enzyme and VPE is a vacuolar enzyme. This implies that the death mechanisms are different between plants and animals. In animal apoptosis, while caspases certainly play a central role, an increasing body of evidence suggests that lysosomal proteases, such as cathepsin B, are involved in the initiation and/or execution of the apoptotic program (Guicciardi et al., 2004). The lysosomal release of cathepsin B into the cytosol is capable of triggering mitochondrial dysfunction with subsequent caspase activation and cellular demise. The lysosomal cathepsin B is processed by AEP (Shirahama-Noda et al., 2003). Plant PCD is accompanied by the up-regulation of a variety of vacuolar hydrolytic enzymes (Fukuda, 2004). VPE could mediate the initial activation of some of these vacuolar enzymes, which then degrade the vacuolar membrane and initiate the proteolytic cascade leading to PCD. These findings suggest that the release of VPE/AEP-dependently-activated enzymes from vacuoles/lysosomes is a common event in both plant and animal PCD. The mechanism by which VPE controls vacuolar rupture is still unclear and could be addressed using the variety of PCD systems that have been described herein.

\section{Acknowledgments}

This work was supported by Grants-in-Aid for Scientific Research to NH (No. 23570043), KY (No. 25440146), and SG (No. 26111523) and a Grant-in-Aid for Specially Promoted Research to IH (No. 22000014) from the Japan Society for the Promotion of Science. 


\section{References}

Atkinson, A. H., Heath, R. L., Simpson, R. J., Clarke, A. E., and Anderson, M. A. (1993). Proteinase inhibitors in Nicotiana alata stigmas are derived from a precursor protein which is processed into five homologous inhibitors. Plant Cell 5, 203-213. doi: 10.1105/tpc.5.2.203

Becker, C., Shutov, A. D., Nong, V. H., Senyuk, V. I., Jung, R., Horstmann, C., et al. (1995). Purification, cDNA cloning and characterization of proteinase B, an asparagine-specific endopeptidase from germinating vetch (Vicia sativa L.) seeds. Eur. J. Biochem. 228, 456-462. doi: 10.1111/j.1432-1033.1995.0456n.x

Bomblies, K., and Weigel, D. (2007). Hybrid necrosis: autoimmunity as a potential gene-flow barrier in plant species. Nat. Rev. Genet. 8, 382-393. doi: $10.1038 / \mathrm{nrg} 2082$

Bonneau, L., Ge, Y., Drury, G. E., and Gallois, P. (2008). What happened to plant caspases? J. Exp. Bot. 59, 491-499. doi: 10.1093/jxb/erm352

Brandwagt, B. F., Mesbah, L. A., Takken, F. L., Laurent, P. L., Kneppers, T. J., Hille, J., et al. (2000). A longevity assurance gene homolog of tomato mediates resistance to Alternaria alternata f. sp. lycopersici toxins and fumonisin B1. Proc. Natl. Acad. Sci. U.S.A. 97, 4961-4966. doi: 10.1073/pnas.97.9.4961

Cai, Y. M., Yu, J., and Gallois, P. (2014). Endoplasmic reticulum stressinduced PCD and caspase-like activities involved. Front. Plant Sci. 5:41. doi: 10.3389/fpls.2014.00041

Chen, J. M., Dando, P. M., Rawlings, N. D., Brown, M. A., Young, N. E., Stevens, R. A., et al. (1997). Cloning, isolation, and characterization of mammalian legumain, an asparaginyl endopeptidase. J. Biol. Chem. 272, 8090-8098. doi: 10.1074/jbc.272.12.8090

Chichkova, N. V., Shaw, J., Galiullina, R. A., Drury, G. E., Tuzhikov, A. I., Kim, S. H., et al. (2010). Phytaspase, a relocalisable cell death promoting plant protease with caspase specificity. EMBO J. 29, 1149-1161. doi: 10.1038/emboj.2010.1

Christoff, A. P., Turchetto-Zolet, A. C., and Margis, R. (2014). Uncovering legumain genes in rice. Plant Sci. 215-216, 100-109. doi: 10.1016/j.plantsci.2013.11.005

Coffeen, W. C., and Wolpert, T. J. (2004). Purification and characterization of serine proteases that exhibit caspase-like activity and are associated with programmed cell death in Avena sativa. Plant Cell 16, 857-873. doi: 10.1105/tpc.017947

Cohen, G. M. (1997). Caspase: the executioners of apoptosis. Biochem. J. 326, 1-16.

Coll, N. S., Epple, P., and Dangl, J. L. (2011). Programmed cell death in the plant immune system. Cell Death Differ. 18, 1247-1256. doi: 10.1038/cdd.2011.37

Dall, E., and Brandstetter, H. (2013). Mechanistic and structural studies on legumain explain its zymogenicity, distinct activation pathways, and regulation. Proc. Natl. Acad. Sci. U.S.A. 110, 10940-10945. doi: 10.1073/pnas.1300686110

Dangl, J. L., and Jones, J. D. (2001). Plant pathogens and integrated defence responses to infection. Nature 411, 826-833. doi: 10.1038/35081161

Danon, A., Rotari, V. I., Gordon, A., Mailhac, N., and Gallois, P. (2004). Ultraviolet-C overexposure induces programmed cell death in Arabidopsis, which is mediated by caspase-like activities and which can be suppressed by caspase inhibitors, p35 and Defender against Apoptotic Death. J. Biol. Chem. 279, 779-787. doi: 10.1074/jbc.M304468200

del Pozo, O., and Lam, E. (1998). Caspases and programmed cell death in the hypersensitive response of plants to pathogens. Curr. Biol. 8, 1129-1132. doi: 10.1016/S0960-9822(98)70469-5

Deng, M., Bian, H., Xie, Y., Kim, Y., Wang, W., Lin, E., et al. (2011). Bcl-2 suppresses hydrogen peroxide-induced programmed cell death via OsVPE2 and OsVPE3, but not via OsVPE1 and OsVPE4, in rice. FEBS J. 278, 4797-4810. doi: 10.1111/j.1742-4658.2011.08380.x

di Toppi, L. S., and Gabbrielli, R. (1999). Response to cadmium in higher plants. J. Exp. Bot. 41, 105-130. doi: 10.1016/S0098-8472(98)00058-6

Dominguez, F., Moreno, J., and Cejudo, F. J. (2001). The nucellus degenerates by a process of programmed cell death during the early stages of wheat grain development. Planta 213, 352-360. doi: 10.1007/s004250000517

Earnshaw, W. C., Martins, L. M., and Kaufmann, S. H. (1999). Mammalian caspases: structure, activation, substrates, and functions during apoptosis. Annu. Rev. Biochem. 68, 383-424. doi: 10.1146/annurev.biochem.68.1.383

Fukuda, H. (2004). Signals that control plant vascular cell differentiation. Nat. Rev. Mol. Cell Biol. 5, 379-391. doi: 10.1038/nrm1364

Gauthier, A., Lamotte, O., Reboutier, D., Bouteau, F., Pugin, A., and Wendehenne, D. (2007). Cryptogein-induced anion effluxes: electrophysiological properties and analysis of the mechanisms through which they contribute to the elicitortriggered cell death. Plant Signal. Behav. 2, 86-95. doi: 10.4161/psb.2.2.4015

Gechev, T. S., and Hille, J. (2005). Hydrogen peroxide as a signal controlling plant programmed cell death. J. Cell Biol. 168, 17-20. doi: 10.1083/jcb.200409170

Gijzen, M., and Nurnberger, T. (2006). Nep1-like proteins from plant pathogens: recruitment and diversification of the NPP1 domain across taxa. Phytochemistry 67, 1800-1807. doi: 10.1016/j.phytochem.2005.12.008

Graham, J. S., Pearce, G., Merryweather, J., Titani, K., Ericsson, H. L., and Ryan, C. A. (1985). Wound-induced proteinase inhibitors from tomato leaves: I The cDNA-deduced primary structure of pre-inhibitor I and its post-translational processing. J. Biol. Chem. 260, 6555-6560.

Greenberg, J. T. (1997). Programed cell death in plant-pathogen interaction. Annu. Rev. Plant Physiol. Plant Mol. Biol. 48, 525-545. doi: 10.1146/annurev.arplant.48.1.525

Greenberg, J. T., and Yao, N. (2004). The role and regulation of programmed cell death in plant-pathogen interactions. Cell. Microbiol. 6, 201-211. doi: 10.1111/j.1462-5822.2004.00361.x

Guicciardi, M. E., Leist, M., and Gores, G. J. (2004). Lysosomes in cell death. Oncogene 23, 2881-2890. doi: 10.1038/sj.onc.1207512

Han, J. J., Lin, W., Oda, Y., Cui, K. M., Fukuda, H., and He, X. Q. (2012). The proteasome is responsible for caspase-3-like activity during xylem development. Plant J. 72, 129-141. doi: 10.1111/j.1365-313X.2012.05070.x

Hara-Nishimura, I. (1998). “Asparaginyl endopeptidase," in Handbook of Proteolytic Enzymes, eds A. J. Barrett, N. D. Rawlings and J. F. Woessner (London, UK: Academic Press), 746-749.

Hara-Nishimura, I. (2012). "Plant legumain, Asparaginyl endopeptidase, Vacuolar processing enzyme," in Handbook of Proteolytic Enzymes 3rd Edn., eds A. J. Barrett, N. D. Rawlings and J. F. Woessner (London, UK: Academic Press), 2314-2320.

Hara-Nishimura, I., and Hatsugai, N. (2011). The role of vacuole in plant cell death. Cell Death Differ. 18, 1298-1304. doi: 10.1038/cdd.2011.70

Hara-Nishimura, I., and Nishimura, M. (1987). Proglobulin processing enzyme in vacuoles isolated from developing pumpkin cotyledons. Plant Physiol. 85, 440-445. doi: 10.1104/pp.85.2.440

Hara-Nishimura, I., Hatsugai, N., Nakaune, S., Kuroyanagi, M., and Nishimura, M. (2005). Vacuolar processing enzyme: an executor of plant cell death. Curr. Opin. Plant Biol. 8, 404-408. doi: 10.1016/j.pbi.2005.05.016

Hara-Nishimura, I., Inoue, K., and Nishimura, M. (1991). A unique vacuolar processing enzyme responsible for conversion of several proprotein precursors into the mature forms. FEBS Lett. 294, 89-93. doi: 10.1016/0014-5793(91) 81349-D

Hara-Nishimura, I., Kinoshita, T., Hiraiwa, N., and Nishimura, M. (1998). Vacuolar processing enzymes in protein-storage vacuoles and lytic vacuoles. J. Plant Physiol. 152, 668-674. doi: 10.1016/S0176-1617(98)80028-X

Hara-Nishimura, I., Takeuchi, Y., and Nishimura, M. (1993). Molecular characterization of a vacuolar processing enzyme related to a putative cysteine proteinase of Schistosoma mansoni. Plant Cell 5, 1651-1659. doi: 10.1105/tpc.5.11.1651

Hatsugai, N., and Hara-Nishimura, I. (2010). Two vacuole-mediated defense strategies in plants. Plant Signal. Behav. 5, 1568-1570. doi: 10.4161/psb.5.12.13319

Hatsugai, N., Iwasaki, S., Tamura, K., Kondo, M., Fuji, K., Ogasawara, K., et al. (2009). A novel membrane fusion-mediated plant immunity against bacterial pathogens. Genes Dev. 23, 2496-2506. doi: 10.1101/gad.1825209

Hatsugai, N., Kuroyanagi, M., Nishimura, M., and Hara-Nishimura, I. (2006). A cellular suicide strategy of plants: vacuole-mediated cell death. Apoptosis 11, 905-911. doi: 10.1007/s10495-006-6601-1

Hatsugai, N., Kuroyanagi, M., Yamada, K., Meshi, T., Tsuda, S., Kondo, M., et al. (2004). A plant vacuolar protease, VPE, mediates virus-induced hypersensitive cell death. Science 305, 855-858. doi: 10.1126/science.1099859

Hiraiwa, N., Nishimura, M., and Hara-Nishimura, I. (1999). Vacuolar processing enzyme is self-catalytically activated by sequential removal of the C-terminal and N-terminal propeptides. FEBS Lett. 447, 213-216. doi: 10.1016/S00145793(99)00286-0

Iakimova, E. T., Sobiczewski, P., Michalczuk, L., Wegrzynowicz-Lesiak, E., Mikicinski, A., and Woltering, E. J. (2013). Morphological and biochemical characterization of Erwinia amylovora-induced hypersensitive cell death in apple leaves. Plant Physiol. Biochem. 63, 292-305. doi: 10.1016/j.plaphy.2012.12.006 
Jennings, C., West, J., Waine, C., Craik, D., and Anderson, M. (2001). Biosynthesis and insecticidal properties of plant cyclotides: the cyclic knotted proteins from Oldenlandia affinis. Proc. Natl. Acad. Sci. U.S.A. 98, 10614-10619. doi: 10.1073/pnas.191366898

Jones, A. M. (2001). Programmed cell death in development and defense. Plant Physiol. 125, 94-97. doi: 10.1104/pp.125.1.94

Jones, J. D., and Dangl, J. L. (2006). The plant immune system. Nature 444, 323-329. doi: $10.1038 /$ nature 05286

Julian, I., Gandullo, J., Santos-Silva, L. K., Diaz, I., and Martinez, M. (2013). Phylogenetically distant barley legumains have a role in both seed and vegetative tissues. J. Exp. Bot. 64, 2929-2941. doi: 10.1093/jxb/ert132

Kadono, T., Tran, D., Errakhi, R., Hiramatsu, T., Meimoun, P., Briand, J., et al. (2010). Increased anion channel activity is an unavoidable event in ozone-induced programmed cell death. PLoS ONE 5:e13373. doi: 10.1371/journal.pone. 0013373

Kangasjärvi, J., Jaspers, P., and Kollist, H. (2005). Signalling and cell death in ozone-exposed plants. Plant Cell Environ. 28, 1021-1036. doi: 10.1111/j.13653040.2005.01325.x

Kariya, K., Demiral, T., Sasaki, T., Tsuchiya, Y., Turkan, I., Sano, T., et al. (2013). A novel mechanism of aluminum-induced cell death involving vacuolar processing enzyme and vacuolar collapse in tobacco cell line BY-2. J. Inorg. Biochem. 128, 196-201. doi: 10.1016/j.jinorgbio.2013.07.001

Kim, Y., Wang, M., Bai, Y., Zeng, Z., Guo, F., Han, N., et al. (2014). Bcl-2 suppresses activation of VPEs by inhibiting cytosolic $\mathrm{Ca}^{2+}$ level with elevated $\mathrm{K}^{+}$ efflux in NaCl-induced PCD in rice. Plant Physiol. Biochem. 80, 168-175. doi: 10.1016/j.plaphy.2014.04.002

Kinoshita, T., Nishimura, M., and Hara-Nishimura, I. (1995a). The sequence and expression of the $\gamma$-VPE gene, one member of a family of three genes for vacuolar processing enzymes in Arabidopsis thaliana. Plant Cell Physiol. 36, $1555-1562$.

Kinoshita, T., Nishimura, M., and Hara-Nishimura, I. (1995b). Homologues of a vacuolar processing enzyme that are expressed in different organs in Arabidopsis thaliana. Plant Mol. Biol. 29, 81-89. doi: 10.1007/BF00019120

Kinoshita, T., Yamada, K., Hiraiwa, N., Kondo, M., Nishimura, M., and HaraNishimura, I. (1999). Vacuolar processing enzyme is up-regulated in the lytic vacuoles of vegetative tissues during senescence and under various stressed conditions. Plant J. 19, 43-53. doi: 10.1046/j.1365-313X.1999.00497.x

Kochian, L. V. (1995). Cellular mechanisms of aluminum toxicity and resistance in plants. Annu. Rev. Plant Physiol. Plant Mol. Biol. 46, 237-260. doi: 10.1146/annurev.pp.46.060195.001321

Kuroyanagi, M., Nishimura, M., and Hara-Nishimura, I. (2002). Activation of Arabidopsis vacuolar processing enzyme by self-catalytic removal of an auto-inhibitory domain of the C-terminal propeptide. Plant Cell Physiol. 43, 143-151. doi: 10.1093/pcp/pcf035

Kuroyanagi, M., Yamada, K., Hatsugai, N., Kondo, M., Nishimura, M., and HaraNishimura, I. (2005). Vacuolar processing enzyme is essential for mycotoxininduced cell death in Arabidopsis thaliana. J. Biol. Chem. 280, 32914-32920. doi: $10.1074 /$ jbc.M504476200

Lam, E., and del Pozo, O. (2000). Caspase-like protease involvement in the control of plant cell death. Plant Mol. Biol. 44, 417-428. doi: 10.1023/A:1026509012695

Li, Z., Yue, H., and Xing, D. (2012). MAP Kinase 6-mediated activation of vacuolar processing enzyme modulates heat shock-induced programmed cell death in Arabidopsis. N. Phytol. 195, 85-96. doi: 10.1111/j.1469-8137.2012.04131.x

Lincoln, J. E., Richael, C., Overduin, B., Smith, K., Bostock, R., and Gilchrist, D. G. (2002). Expression of the antiapoptotic baculovirus p35 gene in tomato blocks programmed cell death and provides broad-spectrum resistance to disease. Proc. Natl. Acad. Sci. U.S.A. 99, 15217-15221. doi: 10.1073/pnas.232579799

Linnestad, C., Doan, D. N., Brown, R. C., Lemmon, B. E., Meyer, D. J., Jung, R., et al. (1998). Nucellain, a barley homolog of the dicot vacuolar-processing protease, is localized in nucellar cell walls. Plant Physiol. 118, 1169-1180. doi: 10.1104/pp.118.4.1169

Liu, Z., Jang, S. W., Liu, X., Cheng, D., Peng, J., Yepes, M., et al. (2008). Neuroprotective actions of PIKE-L by inhibition of SET proteolytic degradation by asparagine endopeptidase. Mol. Cell 29, 665-678. doi: 10.1016/j.molcel.2008.02.017

Markham, J. E., and Hille, J. (2001). Host-selective toxins as agents of cell death in plant-fungus interactions. Mol. Plant. Pathol. 2, 229-239. doi: 10.1046/j.14646722.2001.00066.x
Mase, K., Mizuno, T., Ishihama, N., Fujii, T., Mori, H., Kodama, M., et al. (2012). Ethylene signaling pathway and MAPK cascades are required for AAL toxininduced programmed cell death. Mol. Plant Microbe. Interact. 25, 1015-1025. doi: 10.1094/MPMI-02-12-0036-R

Mendes, G. C., Reis, P. A., Calil, I. P., Carvalho, H. H., Aragao, F. J., and Fontes, E. P. (2013). GmNAC30 and GmNAC81 integrate the endoplasmic reticulum stress- and osmotic stress-induced cell death responses through a vacuolar processing enzyme. Proc. Natl. Acad. Sci. U.S.A. 110, 19627-19632. doi: 10.1073/pnas.1311729110

Mino, M., Murata, N., Date, S., and Inoue, M. (2007). Cell death in seedlings of the interspecific hybrid of Nicotiana gossei and N. tabacum; possible role of knoblike bodies formed on tonoplast in vacuolar-collapse-mediated cell death. Plant Cell Rep. 26, 407-419. doi: 10.1007/s00299-006-0261-z

Misas-Villamil, J. C., Toenges, G., Kolodziejek, I., Sadaghiani, A. M., Kaschani, F., Colby, T., et al. (2013). Activity profiling of vacuolar processing enzymes reveals a role for VPE during oomycete infection. Plant J. 73, 689-700. doi: $10.1111 /$ tpj.12062

Moeder, W., Urquhart, W., Ung, H., and Yoshioka, K. (2011). The role of cyclic nucleotide-gated ion channels in plant immunity. Mol. Plant 4, 442-452. doi: $10.1093 / \mathrm{mp} / \mathrm{ssr} 018$

Muller, G. L., Drincovich, M. F., Andreo, C. S., and Lara, M. V. (2010). Role of photosynthesis and analysis of key enzymes involved in primary metabolism throughout the lifespan of the tobacco flower. J. Exp. Bot. 61, 3675-3688. doi: $10.1093 /$ jxb/erq187

Nakaune, S., Yamada, K., Kondo, M., Kato, T., Tabata, S., Nishimura, M., et al. (2005). A vacuolar processing enzyme, $\delta \mathrm{VPE}$, is involved in seed coat formation at the early stage of seed development. Plant Cell 17, 876-887. doi: 10.1105/tpc.104.026872

Nelson, P. E., Desjardins, A. E., and Plattner, R. D. (1993). Fumonisins, mycotoxins produced by fusarium species: biology, chemistry, and significance. Annu. Rev. Phytopathol. 31, 233-252. doi: 10.1146/annurev.py.31.090193.001313

Nicholson, D. W. (1999). Caspase structure, proteolytic substrates, and function during apoptotic cell death. Cell Death Differ. 6, 1028-1042. doi: 10.1038/si.cdd.4400598

Overmyer, K., Brosche, M., Pellinen, R., Kuittinen, T., Tuominen, H., Ahlfors, R., et al. (2005). Ozone-induced programmed cell death in the Arabidopsis radical-induced cell death1 mutant. Plant Physiol. 137, 1092-1104. doi: 10.1104/pp.104.055681

Pasqualini, S., Piccioni, C., Reale, L., Ederli, L., Della Torre, G., and Ferranti, F. (2003). Ozone-induced cell death in tobacco cultivar Bel W3 plants. The role of programmed cell death in lesion formation. Plant Physiol. 133, 1122-1134. doi: 10.1104/pp.103.026591

Qiang, X., Zechmann, B., Reitz, M. U., Kogel, K. H., and Schafer, P. (2012). The mutualistic fungus Piriformospora indica colonizes Arabidopsis roots by inducing an endoplasmic reticulum stress-triggered caspase-dependent cell death. Plant Cell 24, 794-809. doi: 10.1105/tpc.111.093260

Qutob, D., Kemmerling, B., Brunner, F., Kufner, I., Engelhardt, S., Gust, A. A., et al. (2006). Phytotoxicity and innate immune responses induced by Nep1-like proteins. Plant Cell 18, 3721-3744. doi: 10.1105/tpc.106.044180

Radchuk, V., Weier, D., Radchuk, R., Weschke, W., and Weber, H. (2010). Development of maternal seed tissue in barley is mediated by regulated cell expansion and cell disintegration and coordinated with endosperm growth. J. Exp. Bot. 62, 1217-1227. doi: 10.1093/jxb/erq348

Rasheva, V. I., and Domingos, P. M. (2009). Cellular responses to endoplasmic reticulum stress and apoptosis. Apoptosis 14, 996-1007. doi: 10.1007/s10495009-0341-y

Rojo, E., Martin, R., Carter, C., Zouhar, J., Pan, S., Plotnikova, J., et al. (2004). VPE $\gamma$ exhibits a caspase-like activity that contributes to defense against pathogens. Curr. Biol. 14, 1897-1906. doi: 10.1016/j.cub.2004.09.056

Sanmartin, M., Jaroszewski, L., Raikhel, N. V., and Rojo, E. (2005). Caspases. Regulating death since the origin of life. Plant Physiol. 137, 841-847. doi: 10.1104/pp.104.058552

Saska, I., Gillon, A. D., Hatsugai, N., Dietzgen, R. G., Hara-Nishimura, I., Anderson, M. A., et al. (2007). An asparaginyl endopeptidase mediates in vivo protein backbone cyclization. J. Biol. Chem. 282, 29721-29728. doi: 10.1074/jbc.M705185200

Shimada, T., Yamada, K., Kataoka, M., Nakaune, S., Koumoto, Y., Kuroyanagi, M., et al. (2003). Vacuolar processing enzymes are essential for proper processing of 
seed storage proteins in Arabidopsis thaliana. J. Biol. Chem. 278, 32292-32299. doi: 10.1074/jbc.M305740200

Shirahama-Noda, K., Yamamoto, A., Sugihara, K., Hashimoto, N., Asano, M., Nishimura, M., et al. (2003). Biosynthetic processing of cathepsins and lysosomal degradation are abolished in asparaginyl endopeptidase-deficient mice. J. Biol. Chem. 278, 33194-33199. doi: 10.1074/jbc.M302742200

Stennicke, H. R., and Salvesen, G. S. (1998). Properties of the caspases. Biochim. Biophys. Acta 1387, 17-31. doi: 10.1016/S0167-4838(98)00133-2

Sticher, L., Hofsteenge, J., Neuhaus, J.-M., Boller, T., and Meins, F. Jr. (1993). Posttranslational processing of a new class of hydroxyproline-containing proteins: prolyl hydroxylation and C-terminal cleavage of tobacco (Nicotiana tabacum) vacuolar chitinase. Plant Physiol. 101, 1239-1247. doi: 10.1104/pp.101.4.1239

Teper-Bamnolker, P., Buskila, Y., Lopesco, Y., Ben-Dor, S., Saad, I., Holdengreber, V., et al. (2012). Release of apical dominance in potato tuber is accompanied by programmed cell death in the apical bud meristem. Plant Physiol. 158, 2053-2067. doi: 10.1104/pp.112.194076

Tian, R., Zhang, G. Y., Yan, C. H., and Dai, Y. R. (2000). Involvement of poly(ADPribose) polymerase and activation of caspase-3-like protease in heat shockinduced apoptosis in tobacco suspension cells. FEBS Lett. 474, 11-15. doi: 10.1016/S0014-5793(00)01561-1

Tran, V., Weier, D., Radchuk, R., Thiel, J., and Radchuk, V. (2014). Caspase-like activities accompany programmed cell death events in developing barley grains. PLoS ONE 9:e109426. doi: 10.1371/journal.pone.0109426

Tsiatsiani, L., van Breusegem, F., Gallois, P., Zavialov, A., Lam, E., and Bozhkov, P. V. (2011). Metacaspases. Cell Death Differ. 18, 1279-1288. doi: $10.1038 /$ cdd.2011.66

Uren, A. G., Orourke, K., Aravind, L., Pisabarro, T. M., Seshagiri, S., Koonin, E. V., et al. (2000). Identification of paracaspases and metacaspases: two ancient families of caspase-like proteins, one of which plays a key role in MALT Lymphoma. Mol. Cell 6, 961-967. doi: 10.1016/S1097-2765(05)00086-9

Urquhart, W., Gunawardena, A. H., Moeder, W., Ali, R., Berkowitz, G. A., and Yoshioka, K. (2007). The chimeric cyclic nucleotide-gated ion channel ATCNGC11/12 constitutively induces programmed cell death in a $\mathrm{Ca}^{2+}$ dependent manner. Plant Mol. Biol. 65, 747-761. doi: 10.1007/s11103-007-9239-7

Vacca, R. A., Valenti, D., Bobba, A., Merafina, R. S., Passarella, S., and Marra, E. (2006). Cytochrome $c$ is released in a reactive oxygen species-dependent manner and is degraded via caspase-like proteases in tobacco Bright-Yellow 2 cells en route to heat shock-induced cell death. Plant Physiol. 141, 208-219. doi: 10.1104/pp.106.078683

van Doorn, W. G., and Woltering, E. J. (2008). Physiology and molecular biology of petal senescence. J. Exp. Bot. 59, 453-480. doi: 10.1093/jxb/erm356

Vartapetian, A. B., Tuzhikov, A. I., Chichkova, N. V., Taliansky, M., and Wolpert, T. J. (2011). A plant alternative to animal caspases: subtilisin-like proteases. Cell Death Differ. 18, 1289-1297. doi: 10.1038/cdd.2011.49

Walton, J. D. (1996). Host-selective toxins: agents of compatibility. Plant Cell 8, 1723-1733. doi: 10.1105/tpc.8.10.1723

Wang, E., Norred, W. P., Bacon, C. W., Riley, R. T., and Merrill, A. H. Jr. (1991). Inhibition of sphingolipid biosynthesis by fumonisins. Implications for diseases associated with Fusarium moniliforme. J. Biol. Chem. 266, 14486-14490.

Wang, H., Li, J., Bostock, R. M., and Gilchrist, D. G. (1996). Apoptosis: a Functional Paradigm for programmed plant cell death induced by a host-selective phytotoxin and invoked during development. Plant Cell 8, 375-391. doi: 10.1105/tpc.8.3.375

Wang, W., Pan, J., Zheng, K., Chen, H., Shao, H., Guo, Y., et al. (2009). Ced-9 inhibits Al-induced programmed cell death and promotes Al tolerance in tobacco. Biochem. Biophys. Res. Commun. 383, 141-145. doi: 10.1016/j.bbrc.2009.03.125

Wang, Y., Hu, D., Zhang, Z., Ma, Z., Zheng, X., and Li, D. (2003). Purification and immunocytolocalization of a novel Phytophthora boehmeriae protein inducing the hypersensitive response and systemic acquired resistance in tobacco and Chinese cabbage. Physiol. Mol. Plant Pathol. 63, 223-232. doi: 10.1016/j.pmpp.2003.12.004

Wei, Z. M., Laby, R. J., Zumoff, C. H., Bauer, D. W., He, S. Y., Collmer, A., et al. (1992). Harpin, elicitor of the hypersensitive response produced by the plant pathogen Erwinia amylovora. Science 257, 85-88. doi: 10.1126/science.1621099

Woltering, E. J. (2010). Death proteases: alive and kicking. Trends Plant Sci. 15, 185-188. doi: 10.1016/j.tplants.2010.02.001

Woltering, E. J., van Der Bent, A., and Hoeberichts, F. A. (2002). Do plant caspases exist? Plant Physiol 130, 1764-1769. doi: 10.1104/pp.006338

Yakimova, E. T., Kapchina-Toteva, V. M., and Woltering, E. J. (2007). Signal transduction events in aluminum-induced cell death in tomato suspension cells. J. Plant Physiol. 164, 702-708. doi: 10.1016/j.jplph.2006.03.018

Yakimova, E. T., Kapchina-Toteva, V. M., Laarhoven, L. J., Harren, F. M., and Woltering, E. J. (2006). Involvement of ethylene and lipid signalling in cadmium-induced programmed cell death in tomato suspension cells. Plant Physiol. Biochem. 44, 581-589. doi: 10.1016/j.plaphy.2006.09.003

Yamada, K., Shimada, T., Kondo, M., Nishimura, M., and Hara- Nishimura, I. (1999). Multiple functional proteins are produced by cleaving Asn-Gln bonds of a single precursor by vacuolar processing enzyme. J. Biol. Chem. 274, 2563-2570. doi: 10.1074/jbc.274.4.2563

Yamada, K., Shimada, T., Nishimura, M., and Hara-Nishimura, I. (2005). A VPE family supporting various vacuolar functions in plants. Physiol. Plant. 123, 369-375. doi: 10.1111/j.1399-3054.2005.00464.x

Yoshioka, K., Moeder, W., Kang, H. G., Kachroo, P., Masmoudi, K., Berkowitz, G., et al. (2006). The chimeric Arabidopsis CYCLIC NUCLEOTIDE-GATED ION CHANNEL11/12 activates multiple pathogen resistance responses. Plant Cell 18, 747-763. doi: 10.1105/tpc.105.038786

Zhang, H., Dong, S., Wang, M., Wang, W., Song, W., Dou, X., et al. (2010). The role of vacuolar processing enzyme (VPE) from Nicotiana benthamiana in the elicitor-triggered hypersensitive response and stomatal closure. J. Exp. Bot. 61, 3799-3812. doi: 10.1093/jxb/erq189

Conflict of Interest Statement: The authors declare that the research was conducted in the absence of any commercial or financial relationships that could be construed as a potential conflict of interest.

Copyright (C) 2015 Hatsugai, Yamada, Goto-Yamada and Hara-Nishimura. This is an open-access article distributed under the terms of the Creative Commons Attribution License (CC BY). The use, distribution or reproduction in other forums is permitted, provided the original author(s) or licensor are credited and that the original publication in this journal is cited, in accordance with accepted academic practice. No use, distribution or reproduction is permitted which does not comply with these terms. 